DOI: $10.19195 / 2300-7729.35 .1$

\title{
Bazy bibliograficzne a POL-index. Plusy i minusy, szanse i zagrożenia (na podstawie doświadczeń BazTech)
}

\section{POL-index - koncepcja, akty prawne}

Koncepcja systemu POL-index została po raz pierwszy zaprezentowana w 2013 r. przez Interdyscyplinarne Centrum Modelowania Matematycznego i Komputerowego Uniwersytetu Warszawskiego (ICM UW) na II Konferencji Konsorcjum BazTech „Bibliograficzne bazy danych i ich rola w rozwoju nauki”, na której przedstawiono:

- główny cel: stworzenie narzędzia pozwalającego na uzyskanie informacji o cytowalności czasopism humanistycznych i społecznych z listy B Wykazu czasopism punktowanych MNiSW [przez inne czasopisma $\mathrm{z}$ tego samego wykazu — przyp. aut.], przyjmując jednocześnie otwartość systemu na inne czasopisma (zarówno polskie, jak i zagraniczne) ${ }^{1}$, których wydawcy są zainteresowani dostarczeniem informacji o publikowanych w nich artykułach;

- alternatywne warianty dostarczania danych: 1) przedstawiciele czasopism w ramach corocznej oceny dokonywanej przez MNiSW; 2) całość danych z baz bibliograficznych; 3) część danych z baz bibliograficznych, a część od przedstawicieli czasopism, którzy wprowadzaliby dane za pomocą interfejsu www i/lub importera XML; dane z baz miałyby w tym przypadku charakter pomocniczy i wymagałyby weryfikacji, zatwierdzenia i ewentualnego uzupełnienia przez przedstawicieli czasopism;

— rezultat powstania POL-indexu: wyznaczanie Polskiego Współczynnika Wpływu (PWW) jako elementu oceny czasopism naukowych ${ }^{2}$.

${ }^{1}$ Koncepcja ewoluowała później w kierunku umożliwienia obliczania PWW dla czasopism ze wszystkich grup nauki.

2 W. Fenrich et al., POL-index - Polska Baza Cytowań, [w:] Bibliograficzne bazy danych $i$ ich rola w rozwoju nauki. II konferencja naukowa Konsorcjum BazTech, Poznań 17-19 kwietnia 
Pierwsza oficjalna wzmianka o POL-indexie pojawiła się w Komunikacie Ministra Nauki i Szkolnictwa Wyższego z dnia 29 maja 2013 r. w sprawie kryteriów i trybu oceny czasopism naukowych ${ }^{3}$, w którym wśród 13 parametrów oceny czasopism naukowych w części B wykazu, nieposiadających współczynnika wpływu (Impact Factor), wymienia się Polski Współczynnik Wpływu, zaznaczając, że będzie on obowiązywał przy ocenie czasopism naukowych od 2014 r. W sposobie obliczania tego wskaźnika opisano dane pozwalające określić liczbę cytowań na potrzeby PWW czasopisma naukowego, które mają być wprowadzane do bazy POL-index. Po raz pierwszy podano też oficjalnie wzór obliczania PWW, uwzględniający parametry czasopism, których pełne rekordy bibliograficzne znajdą się w bazie POL-index, w tym liczby cytowañ ${ }^{4} \mathrm{w}$ obrębie artykułów oraz liczby cytowanych artykułów w różnym czasie ${ }^{5}$.

System POL-index nie powstał niestety w planowanym terminie, w związku z czym ocena czasopism w 2014 r. nie uwzględniała zapowiadanego współczynnika PWW, a wykaz czasopism punktowanych opracowano w tym samym roku na podstawie kryteriów z Komunikatu MNiSW z 29 maja 2013 r. ${ }^{6}$

Kolejna informacja o POL-indexie pojawiła się w oficjalnych dokumentach w styczniu 2015 r., w ustawie wprowadzającej zmiany w ustawie o zasadach finansowania nauki ${ }^{7}$. Zmiana dotyczyła np. wprowadzenia zapisów o Systemie Informacji o Nauce w ramach Zintegrowanego Systemu Informacji o Nauce i Szkolnictwie Wyższym - POL-on, obejmującego m.in. dane o działalności badawczo-rozwojowej jednostek naukowych i jej efektach ${ }^{8}$. System Informacji

2013, „EBIB - Materiały Konferencyjne” 24, http://open.ebib.pl/ojs/index.php/Mat_konf/article/ view/40/ [dostęp: 13.02.2017].

${ }^{3}$ Komunikat Ministra Nauki i Szkolnictwa Wyższego z dnia 29 maja 2013 r. w sprawie kryteriów i trybu oceny czasopism naukowych.

4 „Przy określaniu liczby cytowań dla potrzeb ustalenia Polskiego Współczynnika Wpływu uwzględnia się jedynie cytowania w obrębie artykułów opublikowanych w czasopismach naukowych nieindeksowanych w bazach Science Citation Index Expanded, Social Science Citation Index oraz Arts \& Humanities Citation Index w celu uniknięcia dwukrotnego zaliczania tych samych cytowań dla potrzeb określenia współczynników Predicted Impact Factor oraz Polskiego Współczynnika Wpływu”. Zob. ibidem.

${ }^{5}$ Ibidem; E. Kulczycki, Polski Wspótczynnik Wpływu, [w:] Warsztat badacza, 25.08.2013, http://ekulczycki.pl/warsztat_badacza/polski-wspolczynnik-wplywu/ [dostęp: 13.02.2017].

${ }^{6}$ Komunikat Ministra Nauki i Szkolnictwa Wyższego z dnia 29 maja 2013 r.; E. Kulczycki, E.A. Rozkosz, A. Drabek, Ocena ekspercka jako trzeci wymiar ewaluacji krajowych czasopism naukowych, „Nauka” 2016, nr 1, s. 108.

${ }^{7}$ Ustawa z dnia 15 stycznia 2015 r. o zmianie ustawy o zasadach finansowania nauki oraz niektórych innych ustaw, Dz.U. 2015, poz. 249; J. Przyłuska, System Informacji o Nauce — zakres danych i informacji objętych systemem, terminy aktualizacji i sposób udostępniania danych, „Biuletyn EBIB" 2016, nr 3 (165), http://open.ebib.pl/ojs/index.php/ebib/article/view/425 [dostęp: 13.02.2017].

${ }^{8}$ Ustawa z dnia 30 kwietnia 2010 r. o zasadach finansowania nauki, Dz.U. 2010, nr 96, poz. 615 z późn. zm. 
o Nauce obejmuje również informacje o cytowaniach publikacji zamieszczonych w polskiej bazie cytowań czasopism naukowych (POL-index) na podstawie informacji uzyskanych od redakcji lub wydawców czasopism naukowych i podmiotów prowadzących bazy bibliograficzne? .

Zakres danych, terminy aktualizacji oraz sposób i forma udostępniania informacji zgromadzonych w Systemie Informacji o Nauce, w tym w POL-indexie, określono w Rozporządzeniu z 29 czerwca 2015 r. w sprawie Systemu Informacji o Nauce (obowiązującym od 4 lipca 2015 r.) ${ }^{10}$. W Załączniku nr 2 przedstawiono szczegółowy zakres informacji o cytowaniach publikacji zamieszczonych w POL-indexie ${ }^{11}$. Na potrzeby rejestracji cytowań pełny rekord bibliograficzny artykułu powinien zawierać: tytuł artykułu, tytuły artykułu w innych językach, typ artykułu, tom, numer, rok, strony od-do, język artykułu, imiona i nazwiska autorów artykułu, afiliacje autorów artykułu, rolę autora w tworzeniu artykułu, język abstraktów, wykaz cytowanej literatury (bibliografia załącznikowa lub jej opracowanie na podstawie odniesień do innych prac zawartych wyłącznie w przypisach dolnych lub końcowych), dziedziny i dyscypliny naukowe dotyczące artykułu, słowa kluczowe oraz nr DOI artykułu. W wymaganych danych nie dokonano podziału na dane obowiązkowe i fakultatywne. Ustalono również, że informacje o cytowaniach są aktualizowane według stanu na dzień 31 grudnia, $w$ terminie do dnia 30 kwietnia następnego roku, bez określenia podmiotów odpowiedzialnych za dostarczanie danych ${ }^{12}$. Nowelizacja tego rozporządzenia została ogłoszona w Rozporządzeniu z dnia 26 lutego 2016 r. zmieniającym rozporządzenie w sprawie Systemu Informacji o Nauce, przy czym zasady i terminy rejestracji cytowań publikacji w bazie POL-index nie uległy zmianie ${ }^{13}$.

Z powyższych przepisów wynika, że najpierw (w styczniu 2015 r.) ustalono obowiązkowe terminy aktualizacji w POL-indexie danych o cytowaniach według stanu na 31 grudnia 2015 r. do końca kwietnia 2016 r. ${ }^{14}$ Natomiast kolejne przepisy mówiły o dobrowolnym zasilaniu POL-indexu ${ }^{15}$.

${ }^{9}$ Ibidem, art. 4c, ust. 4, p. 2.

${ }^{10}$ Rozporządzenie Ministra Nauki i Szkolnictwa Wyższego z dnia 29 czerwca 2015 r. w sprawie Systemu Informacji o Nauce, Dz.U. 2015, poz. 944.

${ }^{11}$ Ibidem, załącznik nr 2.

12 Ibidem, par. 3, p. 6.

${ }^{13}$ Rozporządzenie Ministra Nauki i Szkolnictwa Wyższego z dnia 26 lutego 2016 r. zmieniające rozporządzenie w sprawie Systemu Informacji o Nauce, Dz.U. 2016, poz. 309.

${ }^{14}$ Ustawa z dnia 15 stycznia 2015 r. o zmianie ustawy o zasadach finansowania nauki oraz niektórych innych ustaw.

${ }^{15}$ Komunikat Ministra Nauki i Szkolnictwa Wyższego z dnia 2 czerwca 2015 r. w sprawie kryteriów i trybu oceny czasopism naukowych; Komunikat w sprawie przedłużenia terminu wprowadzania danych do polskiej bazy cytowań POL-index — pismo Sekretarza Stanu prof. Marka Ratajczaka z dnia 20 lipca 2015 r., http://www.nauka.gov.pl/komunikaty/komunikat-wsprawie-przedluzenia-terminu-wprowadzania-danych-do-polskiej-bazy-cytowan-pol-index.html [dostęp: 13.02.2017]. 
2 czerwca 2015 r. ogłoszone zostały przez MNiSW nowe kryteria i tryb oceny czasopism naukowych ${ }^{16}$. Czasopisma naukowe $\mathrm{z}$ tzw. listy B były oceniane na podstawie informacji zawartych w ankietach, które należało wypełniać on-line od 15 czerwca do 15 lipca 2015 r. Wśród 11 parametrów oceny czasopism znalazło się kryterium POL-index, za którego spełnienie - skuteczne wprowadzenie do POL-indexu danych zawierających pełne rekordy bibliograficzne artykułów opublikowanych w ciągu dwóch lub sześciu lat poprzedzających rok złożenia ankiety - czasopismo mogło uzyskać punkty ${ }^{17}$. Informację o spełnieniu warunku miał dostarczyć operator merytoryczny POL-indexu i za wprowadzenie pełnych danych z sześciu lat można było otrzymać 2 punkty, a z dwóch lat - 1 punkt. W wymienionym Komunikacie MNiSW podano elementy pełnych danych (rekordów bibliograficznych wszystkich artykułów opublikowanych w czasopiśmie naukowym), spośród których obowiązkowe są: tom/numer, rok, tytuł artykułu, typ artykułu, język artykułu, imiona i nazwiska autorów, wykaz cytowanej literatury. Do danych fakultatywnych zaliczono: tytuł artykułu w innych językach, strony od-do, afiliacje autorów, rolę autora w tworzeniu artykułu, języki abstraktów, dziedziny naukowe dotyczące artykułu, dyscypliny naukowe dotyczące artykułu, słowa kluczowe oraz nr DOI artykułu ${ }^{18}$. W dokumencie nie doprecyzowano terminów wprowadzenia danych bibliograficznych do POL-indexu, określając jednocześnie termin złożenia ankiety czasopisma do 15 lipca 2015 r., co niektórzy wypełniający te ankiety interpretowali jako dokładnie taki sam termin zasilenia danymi POL-indexu.

Wdrożenie POL-indexu zapowiedziano na 20 lipca 2015 r., a w witrynie systemu pojawił się komunikat informujący o terminie wprowadzenia danych do połowy września. Biorąc pod uwagę zakres danych (z dwóch lub sześciu lat), ich „ręczne” dodanie do POL-indexu — poprzez interfejs www — w przypadku miesięczników było niemalże niewykonalne ${ }^{19}$. Ostatecznie MNiSW wydłużyło termin do 13 października, informując jednocześnie, że po jego upływie nadal będzie możliwe uzupełnianie i korygowanie wprowadzonych informacji, oraz podkreślając, że wprowadzanie danych do POL-indexu ma w 2015 r. charakter dobrowolny, a jego niewypełnienie nie skutkuje żadnymi sankcjami. Dotyczyło to ponadto jedynie czasopism $\mathrm{z}$ list $\mathrm{B}$ oraz $\mathrm{C}$, dla których za zaangażowanie $\mathrm{W}$ realizację tego zadania $\mathrm{w}$ ramach oceny czasopism w $2015 \mathrm{r}$. przewidziano wspomnianą wyżej gratyfikację w postaci dodatkowych punktów ${ }^{20}$.

${ }^{16}$ Komunikat Ministra Nauki i Szkolnictwa Wyższego z dnia 2 czerwca 2015 r.

${ }^{17}$ Ibidem.

18 Ibidem, załącznik nr 3.

19 D. Flis, Zmora humanistów - bibliografia, „Gazeta Wyborcza” 17.08.2015, http://wyborcza.pl/1,75398,18579671,zmora-humanistow-bibliografia.html [dostęp: 13.02.2017].

${ }^{20}$ Komunikat w sprawie przedłużenia terminu wprowadzania danych do Polskiej Bazy Cytowań POL-Index. 
Omawiając koncepcję systemu POL-index, nie można pominąć informacji zawartych w jego aktualnej witrynie. Ze strony głównej dowiadujemy się, że

POL-index ma na celu zebranie informacji o artykułach publikowanych w polskich czasopismach naukowych oraz cytowań w tych artykułach. W oparciu o zgromadzone dane wyznaczony zostanie Polski Współczynnik Wpływu (PWW) ${ }^{21}$.

\section{W zakładce Pomoc czytamy:}

możliwość wprowadzania danych do POL-index otwarta jest dla wszystkich czasopism naukowych, niezależnie od rodzaju, kraju pochodzenia, tematyki czy faktu ewaluacji na dowolnym wykazie Ministra Nauki i Szkolnictwa Wyższego. Jednakże jest wyjątkowo ważnym, aby dane dostarczyły czasopisma ubiegające się o ocenę w obrębie Części B Wykazu Czasopism Punktowanych. Dane te staną się podstawą dla obliczenia Polskiego Współczynnika Wpływu, który stanie się elementem oceny czasopism w roku $2017^{22}$.

Pojawia się tu zatem wyraźna zachęta do wprowadzania danych przez redakcje czasopism ze wszystkich tzw. list $\mathrm{MNiSW}^{23}$ oraz zapowiedź uwzględniania PWW w 2017 r., co zostało też potwierdzone zapisami w Rozporządzeniu Ministra Nauki i Szkolnictwa Wyższego z dnia 27 października 2015 r. w sprawie kryteriów i trybu przyznawania kategorii naukowej jednostkom naukowym ${ }^{24}$. W witrynie POL-indexu znajdujemy również informację o planowanych zmianach w definicji PWW:

Operator merytoryczny PBN, w porozumieniu z Zespołem Specjalistycznym Ministra Nauki i Szkolnictwa Wyższego, postanowił usunąć dotychczasową definicję Polskiego Współczynnika Wpływu, prezentowaną dotychczas na stronach Polskiej Bibliografii Naukowej. Uznaliśmy wspólnie, iż prace merytoryczne nad kształtem PWW, określeniem zasad zliczania cytowań (szereg czasowy, rodzaje artykułów, źródło cytowań, mechanizmy zakładające różnicowanie siły cytowań etc.), winny być oparte na faktycznych danych i uwzględniać najlepsze światowe doświadczenia w tej dziedzinie. Eksperci Index Copernicus International (ICI) we współpracy ze środowiskiem naukowym, członkami zespołu przedstawią i poddadzą pod dyskusję nową koncepcję PWW w oparciu o dane zgromadzone w toku ewaluacji 2015 roku. [...] Podstawowym

${ }^{21}$ POL-index, https://pbn.nauka.gov.pl/polindex-webapp/ [dostęp: 13.02.2017].

22 POL-index — serwis informacyjny, http://polindex-pomoc.opi.org.pl/index.php [dostęp: 13.02.2017].

${ }^{23}$ We wcześniejszych wersjach witryny POL-indexu — zarchiwizowanych w lipcu $2014 \mathrm{r}$. i marcu 2015 r. - zamieszczono informację: „System POL-index ma na celu zebranie informacji o artykułach opublikowanych w czasopismach naukowych ubiegających się o ocenę w ramach tzw. listy B oraz wykazach cytowanej w nich literatury. Informacje te pozwolą na dokonanie analizy cytowalności tych czasopism". Zob. https://web.archive.org/web/20140726161511/https://pbn. nauka.gov.pl/polindex/info/ [dostęp: 13.02.2017].

${ }^{24}$ Rozporządzenie Ministra Nauki i Szkolnictwa Wyższego z dnia 27 października 2015 r. w sprawie kryteriów i trybu przyznawania kategorii naukowej jednostkom naukowym, Dz.U. 2015, poz. 2015. 
założeniem Polskiego Współczynnika Wpływu jest uzależnienie jego obliczenia wyłącznie dla tych czasopism, które dostarczą kompletne dane w systemie POL-index ${ }^{25}$.

\section{POL-index - zarządzanie, zawartość}

Powstanie POL-indexu i zarządzanie nim w pierwszych latach funkcjonowania opisują Piotr Brzeziński, Katarzyna Szewczuk i Wioleta Kiliszek, nie szczędząc krytyki twórcom i pierwszemu operatorowi systemu - ICM UW ${ }^{26}$. Brzeziński i in. zarzucają twórcom POL-indexu przede wszystkim brak merytorycznego, technicznego i technologicznego skoordynowania z Polską Bibliografią Naukową (PBN) oraz brak mechanizmu rozpoznawania i analizy cytowań $^{27}$. ICM UW było również pierwszym operatorem POL-indexu przed jego publicznym wdrożeniem. Jesienią 2014 r. Ośrodek Przetwarzania Informacji - Państwowy Instytut Badawczy (OPI-PIB), na zlecenie MNiSW (właściciela systemu), ogłosił przetarg na wyłonienie nowego operatora technicznego i merytorycznego POL-indexu na okres 12 miesięcy od daty zawarcia umowy, którą podpisano ostatecznie 8 kwietnia $2015 \mathrm{r}$. z ICI. POL-index został ostatecznie wdrożony dopiero 20 lipca $2015 \mathrm{r}$.

Do 13 października 2015 r. (termin wprowadzenia i zatwierdzenia danych $\mathrm{o}$ artykułach z czasopism z listy B) kompletne dane wprowadziły do POL-indexu redakcje 1578 (71,4\%) czasopism, z czego $1074(48,6 \%)$ z sześciu lat, a 504 (22,8\%) — z dwóch lat. W tej liczbie znalazło się 75,7\% czasopism z listy B z nauk ścisłych, technicznych, medycznych i przyrodniczych, $75,5 \%$ - z grupy nauk społecznych oraz $62,8 \%$ z grupy nauk humanistycznych ${ }^{28}$. Łącznie w 2015 r. zgromadzono w POL-indexie 385847 opisów publikacji z lat 2009-2014, z czego: 30\% z zakresu nauk społecznych, 20\% — humanistycznych i 50\% — ścisłych, technicznych, medycznych i przyrodniczych. Publikacje zawierają 6191795 cytowań $^{29}$.

Od kwietnia 2016 r. operatorem POL-indexu jest OPI-PIB. Kolejny raz zmiana operatora nastąpiła w momencie ważnym dla redakcji czasopism, które zgodnie z przepisami do 30 kwietnia powinny przekazać dane artykułów opublikowanych rok wcześniej, w tym przypadku w 2015 r. Tak częste zmiany operatora nie są ko-

25 POL-index — zakładka Polski Współczynnik Wpływu, https://pbn.nauka.gov.pl/polindex-webapp/ [dostęp: 13.02.2017].

${ }^{26}$ P. Brzeziński, K. Szewczuk, W. Kiliszek, Polska Bibliografia Naukowa, Modut Sprawozdawczy i system POL-index oczami dotychczasowego operatora systemu - nowości, wyzwania, podsumowanie, „Biuletyn EBIB” 2016, nr 3 (165), http://open.ebib.pl/ojs/index.php/ebib/ article/view/432 [dostęp: 13.02.2017].

27 Ibidem.

${ }^{28}$ E. Kulczycki, E.A. Rozkosz, A. Drabek, op. cit., s. 128.

${ }^{29}$ P. Brzeziński, K. Szewczuk, W. Kiliszek, op. cit., s. 19. 
rzystne dla samego systemu POL-index, a szczególnie dla osób odpowiedzialnych za wprowadzanie danych z czasopism.

\section{Bazy bibliograficzne wobec POL-indexu}

Omawiając udział krajowych baz bibliograficznych w zasilaniu POL-indexu danymi, ograniczymy się do tych baz, które aktywnie w tym procesie uczestniczyły. Zaangażowanie twórców baz danych przejawiało się przede wszystkim w zajmowaniu stanowiska wobec koncepcji funkcjonowania POL-indexu, jak również we wspieraniu redakcji i wydawców czasopism we wprowadzaniu danych. Do tych baz należą głównie serwisy współpracujące z ICM UW i współtworzące zasoby Biblioteki Nauki: AGRO, BazEkon, BazTech, CEJSH, DMLPL, PSJD ${ }^{30}$.

Twórcy baz od samego początku żywo interesowali się koncepcją POL-inde$\mathrm{xu}$, czego dowodem była poświęcona temu specjalna sesja podczas II Konferencji Konsorcjum BazTech ${ }^{31}$, na której po raz pierwszy publicznie zaprezentowano testową wersję interfejsu www do wprowadzania danych do POL-indexu. W maju 2013 r. przedstawiciele baz bibliograficznych zostali zaproszeni do MNiSW na rozmowę o serwisach bibliograficznych w POL-on, w trakcie której Konsorcjum BazTech zaprezentowało (wspólną z innymi bazami) wizję POL-indexu. Polegała ona przede wszystkim na założeniu, że dziedzinowe bazy danych powinny stanowić materiał wyjściowy dla polskiego indeksu cytowań, który mógłby być przez redakcje czasopism weryfikowany i zatwierdzany ${ }^{32}$.

Wiosną 2013 r. MNiSW zaproponowało twórcom baz podpisanie umów, których przedmiotem byłyby zasady korzystania z metadanych i pełnych treści określonej bazy bibliograficznej w systemie Polska Bibliografia Naukowa oraz w systemie POL-index. Treść umów budziła wiele wątpliwości natury prawnej i organizacyjnej, więc twórcy baz przekazali do MNiSW swoje propozycje zmian. Rozstrzygnięcia wymagały przede wszystkim kwestie licencyjne, gdyż większość baz bibliograficznych, pomimo dostępności w sieci bez opłat, nie udostępnia metadanych w otwartym dostępie. Od jesieni 2013 r. ze strony MNiSW nie wpływały żadne informacje ani kolejne propozycje. Ten brak dalszej komunikacji spowo-

30 Wszystkie wymienione bazy były prezentowane na Bibliograficzne bazy danych i ich rola w rozwoju nauki. II Konferencji Konsorcjum BazTech, Poznań 17-19.04.2013, http://hps.biblos. pk.edu.pl/bbd13/strona_glowna [dostęp: 13.02.2017] oraz na seminariach z cyklu Jak zwiększyć zasięg $i$ wplyw czasopisma naukowego?, z których ostatnie odbyło się w Warszawie 20 kwietnia 2015 r., http://pon.edu.pl/index.php/post?pid=58 [dostęp: 13.02.2017].

${ }^{31}$ Bibliograficzne bazy danych i ich rola $w$ rozwoju nauki...

${ }^{32}$ L. Derfert-Wolf, Indeksowanie czasopism naukowych w krajowych bazach danych w kontekście organizacyjno-ekonomicznym, [w:] Biblioteka akademicka: infrastruktura - uczelnia otoczenie, red. M. Odlanicka-Poczobutt, K. Zioło, Gliwice 2014, s. 201-204. 
dował wiele zróżnicowanych opinii — nie zawsze bazujących na faktach — na temat przyszłej współpracy baz bibliograficznych z POL-indexem. Dowodem tego była pełna emocji dyskusja na blogu Emanuela Kulczyckiego Warsztat badacza ${ }^{33}$. W celu wyjaśnienia wszelkich niejasności 26 czerwca 2015 r. twórcy baz przesłali do MNiSW, do zespołu specjalistycznego, do oceny czasopism oraz do OPI-PIB, pismo wyjaśniające fakty oraz deklarujące gotowość przekazania przedstawicielom indeksowanych czasopism danych wymaganych w POL-indexie, w formie umożliwiającej import do tego systemu.

7 lipca 2015 r. w witrynie Platformy Otwartej Nauki (PON) w ICM UW koordynującej tworzenie Biblioteki Nauki — zamieszczono informację dotyczącą wsparcia czasopism indeksowanych w bazach bibliograficznych AGRO, BazEkon, BazTech, CEJSH, PSJD i DML PL we wprowadzaniu danych do POL-indexu ${ }^{34}$. $\mathrm{W}$ komunikacie poinformowano, że przedstawiciele indeksowanych w tych bazach czasopism będą mogli po 20 lipca 2015 r. otrzymać dane wchodzące w zakres wymagany w systemie POL-index ${ }^{35}$. Jednocześnie w ICM UW trwały prace nad narzędziem, dzięki któremu bazy bibliograficzne tworzące Bibliotekę Nauki mogły wyeksportować dane w odpowiednim formacie i przekazać je wydawcom. Podobnie uczyniła Biblioteka Główna Uniwersytetu Ekonomicznego w Krakowie, koordynator bazy BazEkon, również wchodzącej w skład Biblioteki Nauki. Prace zakończono we właściwym czasie i 20 lipca 2015 r. w witrynie PON zamieszczono komunikat ${ }^{36}$, w którym podano tryb uzyskiwania danych przez redakcje czasopism, podkreślając, że pełna odpowiedzialność za kompletność i poprawność danych w systemie POL-index spoczywa na przedstawicielach czasopism. Inicjatywa została również upowszechniona przez $\mathrm{MNiSW}^{37}$.

Współpraca poszczególnych baz bibliograficznych z przedstawicielami czasopism przebiegała dalej odrębnie. Do 13 października 2015 r. przekazano dane łącznie 613 czasopismom (rozkład według baz danych przedstawiono w tabeli 1). Biorąc pod uwagę, że do systemu POL-index dane zostały poprawnie wprowadzone przez 1578 czasopism $^{38}$, bazy bibliograficzne wsparły z tej liczby $39 \%$ czasopism.

${ }^{33}$ E. Kulczycki, Zasady oceny czasopism w 2015: omówienie i komentarz, [w:] Warsztat badacza, 3.06.2015, http://ekulczycki.pl/warsztat_badacza/zasady-oceny-czasopism-w-2015-omowienie-i-komentarz/ [dostęp: 13.02.2017].

${ }^{34}$ Informacja dotycząca wsparcia dla czasopism indeksowanych w bazach bibliograficznych AGRO, BazEkon, BazTech, CEJSH, PSJD i DML PL we wprowadzeniu danych do systemu POL-index, http://pon.edu.pl/index.php/post?pid=68 [dostęp: 13.02.2017].

35 Termin uruchomienia POL-indexu w formie umożliwiającej wprowadzanie danych do systemu przez przedstawicieli czasopism - 20 lipca 2015 r. — ogłoszono na witrynie POL-indexu.

36 Wsparcie czasopism we wprowadzaniu danych do systemu POL-index, http://pon.edu.pl/ index.php/post?pid=71 [dostęp: 13.02.2017].

${ }^{37}$ Komunikat w sprawie przedłużenia terminu wprowadzania danych do polskiej bazy cytowań POL-index.

${ }^{38}$ E. Kulczycki, E.A. Rozkosz, A. Drabek, op. cit., s. 128. 
Tabela 1. Dane przekazywane redakcjom przez bazy bibliograficzne w celu importowania do POL-indexu

\begin{tabular}{|c|c|c|c|c|c|c|c|}
\hline \multirow[b]{2}{*}{$\begin{array}{l}\text { Dane z czasopism przekazy- } \\
\text { wane redakcjom przez bazy } \\
\text { bibliograficzne }\end{array}$} & \multicolumn{7}{|c|}{ Liczba czasopism } \\
\hline & 兄 & 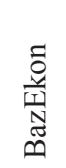 & 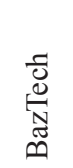 & 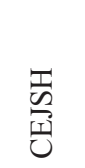 & 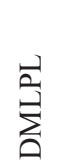 & $\underset{\mathscr{D}}{\stackrel{a}{n}}$ & $\begin{array}{l}\text { Eี } \\
\text { స్ } \\
\simeq\end{array}$ \\
\hline $\begin{array}{l}\text { dane } \mathrm{z} \text { lat 2009-2014 przeka- } \\
\text { zane w } 2015 \text { r.* }\end{array}$ & 65 & 182 & 216 & 136 & 4 & 10 & 613 \\
\hline $\begin{array}{l}\text { dane z } 2015 \text { r. przekazane } \\
\text { w } 2016 \text { r.** }\end{array}$ & 31 & 22 & 172 & 50 & 0 & 2 & 277 \\
\hline $\begin{array}{l}\text { dane przekazywane po kwiet- } \\
\text { niu } 2016 \text { r.*** }\end{array}$ & 1 & 14 & 20 & $\begin{array}{l}\text { więk- } \\
\text { szość }\end{array}$ & nie & nie & \\
\hline $\begin{array}{l}\text { dane } \mathrm{z} \text { lat } 2009-2015 \text { przeka- } \\
\text { zane w } 2016 \mathrm{r} \text {.**** }^{* *}\end{array}$ & 1 & nie & 9 & $\begin{array}{l}\text { ok. } \\
\text { poło- } \\
\text { wy }\end{array}$ & nie & 2 & \\
\hline
\end{tabular}

Źródło: opracowanie własne na podstawie informacji zebranych 26 sierpnia 2016 r.

* Pliki przesłane redakcjom od 20 lipca do 13 października 2015 r. w ramach spełniania kryterium POL-index przy ocenie czasopism przez MNiSW w $2015 \mathrm{r}^{39}$

** Pliki przesłane redakcjom w 2016 r. w związku z obowiązkiem sprawozdawczym jednostek naukowych ${ }^{40}$.

*** Pliki przesłane redakcjom w 2016 r., po ustawowym terminie.

**** Pliki przesłane redakcjom w 2016 r., w szerszym zakresie niż przewidziano w ustawie (tylko dane z 2015 r.) $)^{41}$.

\section{Doświadczenia BazTech — dobre praktyki}

Pierwsze kontakty BazTech z redakcjami czasopism w sprawie przekazywania danych do POL-indexu miały miejsce już na początku 2014 r. Było to konsekwencją zapowiedzi oceny czasopism w 2014 r. na podstawie PWW, w dokumentach oficjalnych ${ }^{42}$ oraz w ówczesnej witrynie testowej wersji POL-indexu ${ }^{43}$. Po wdrożeniu POL-indexu w lipcu 2015 r. i opisanych wspólnych działaniach baz bibliograficznych $\mathrm{w}$ zakresie wsparcia redakcji czasopism $\mathrm{w}$ witrynie Baz-

${ }^{39}$ Komunikat Ministra Nauki i Szkolnictwa Wyższego z dnia 2 czerwca 2015 r.

${ }^{40}$ Ustawa z dnia 15 stycznia 2015 r. o zmianie ustawy o zasadach finansowania nauki oraz niektórych innych ustaw.

${ }^{41}$ Ibidem.

42 Komunikat Ministra Nauki i Szkolnictwa Wyższego z dnia 29 maja 2013 r.

43 https://web.archive.org/web/20140726161511/https://pbn.nauka.gov.pl/polindex/info/ [dostęp: 13.02.2017]. 
Tech zamieszczono oficjalny komunikat, w którym poinformowano o możliwości otrzymania wymaganych w POL-indexie danych ${ }^{44}$.

W ramach Konsorcjum BazTech za przekazywanie danych redakcjom czasopism odpowiedzialny był zespół koordynatorów z Biblioteki Głównej Uniwersytetu Technologiczno-Przyrodniczego w Bydgoszczy. Zgłoszenia z redakcji wpływały na jedno wskazane konto poczty elektronicznej. W mailach redaktorzy powoływali się na informacje podane na stronach MNiSW, PON, BazTech. Najczęściej kierowali ogólną prośbę o przekazanie danych czasopisma w celu ich importu do bazy POL-index. Niektórzy, poza tytułem czasopisma, podawali ISSN oraz wymagany zakres chronologiczny danych, np. 2009-2014. Zdarzały się też lakoniczne maile z trudnych do zidentyfikowania kont o treści: „Proszę o dane do POL-index".

Każde zgłoszenie było najpierw analizowane w bazie BazTech pod kątem kompletności wymaganych danych. W razie niezindeksowanych numerów/roczników biblioteka odpowiedzialna w Konsorcjum za dane czasopismo była zobligowana do pilnego uzupełnienia braków. Czasopisma, których redakcje zgłaszały prośby o dane do POL-indexu, analizowano w bazie pod kątem:

— aktualności danych wydawniczych, redakcyjnych itp.,

- występowania okładki w wersji elektronicznej,

— występowania w bazie w wersji pełnotekstowej.

$\mathrm{W}$ razie niespełnienia powyższych warunków kontaktowano się z redakcją i uzupełniano dane oraz przedstawiano zasady udostępniania pełnych tekstów artykułów w bazie danych BazTech. Przy tej okazji pozyskano kilka nowych czasopism w wersji pełnotekstowej.

Pliki .xml z danymi o artykułach, gotowe do wyeksportowania do POL-indexu, przekazywane były osobom odpowiedzialnym z poszczególnych czasopism wraz z instrukcją postępowania. Redakcje proszono o potwierdzanie otrzymania danych oraz ich eksportu do POL-indexu. W razie jakichkolwiek problemów koordynatorzy BazTech starali się pomagać redaktorom czasopism, w miarę swoich możliwości. Utrudnieniem był brak wglądu do danych w POL-indexie i często pomoc odbywała się na zasadzie „prób i błędów”. Najczęściej spotykanymi problemami były zmiany tytułów i numerów ISSN, które zostały automatycznie zaimportowane z PBN jako podstawowe dane czasopisma wprowadzane na potrzeby złożenia ankiety ewaluacyjnej MNiSW. W przypadku rozbieżności pomiędzy numerem ISSN zgłoszonym w PBN a numerem w BazTech należało te dane ujednolicać. Niekiedy odbywało się to wyłącznie przy pomocy administratorów POL-indexu.

We wrześniu 2015 r. - miesiąc przez ostatecznym terminem wprowadzenia danych do POL-indexu przez redakcje czasopism — przeprowadzono szczegółową analizę tytułów indeksowanych w BazTech, znajdujących się na liście B

${ }^{44}$ BazTech - baza danych o zawartości polskich czasopism technicznych. 
czasopism punktowanych przez MNiSW. W wyniku analizy okazało się, że kilkadziesiąt redakcji nie zgłosiło potrzeby otrzymania danych z BazTech. Wyszukiwania w POL-indexie ujawniły, że część z nich miała już wprowadzone dane (często z lat 2009-2014). Z bezpośrednich kontaktów z redakcjami wynikało, że niektóre otrzymały dane w plikach .xml od dostawców platform elektronicznych wersji czasopism, np. Portal Czasopism Naukowych UJ, de Gruyter czy Index Copernicus International, a inne wprowadziły je „ręcznie” we własnym zakresie, gdyż nie dotarła do nich żadna informacja o możliwości skorzystania z pomocy baz bibliograficznych. W wyniku powyższej analizy do kilkudziesięciu redakcji czasopism skierowano maile $\mathrm{z}$ ofertą bezpłatnej pomocy w imporcie danych. Skorzystała z niej tylko część adresatów. Kolejną formą dotarcia do czasopism były bezpośrednie kontakty redaktorów BazTech z wydawnictwami uczelnianymi oraz redakcjami czasopism w instytutach, katedrach itp. Analiza danych w POL-indexie wskazuje, że pewna grupa czasopism — mimo dostarczonych pełnych informacji — nie była zainteresowana wprowadzeniem danych do systemu.

$\mathrm{W}$ rezultacie wsparcia czasopism naukowych z zakresu nauk technicznych w 2015 r. Konsorcjum BazTech przekazało pliki .xml z danymi gotowymi do wyeksportowania do POL-indexu z 216 czasopism. W plikach znalazły się opisy ok. 82 tys. artykułów z roczników 2009-2014. Całe przedsięwzięcie trwało od 1 sierpnia do 13 października. Należy tu dodać, że prace w ramach samego Konsorcjum wymagały dobrej organizacji i szybkiego reagowania na potrzeby redakcji czasopism. Zdarzało się bowiem, że wymaganych danych nie było jeszcze w bazie i w trybie pilnym je uzupełniano.

Warto podkreślić, że wprowadzanie danych do POL-indexu w 2015 r. wynikało z możliwości otrzymania dodatkowych punktów w ramach ewaluacji czasopism przez MNiSW i było dobrowolne. Inaczej sytuacja wyglądała w 2016 r., gdyż zgodnie z omówionymi wcześniej aktami prawnymi dotyczącymi Systemu Informacji o Nauce redakcje lub wydawcy czasopism naukowych powinni wprowadzić do POL-indexu (do końca kwietnia 2016 r.) dane o artykułach i cytowaniach z $2015 \mathrm{r} .{ }^{45} \mathrm{Na}$ początku $2016 \mathrm{r}$. zaledwie kilka redakcji czasopism zwróciło się do Konsorcjum BazTech o dane. W ramach przygotowań do przekazywania plików .xml dokonano przeglądu aktualności danych z 2015 r. w bazie i ustalono terminy ich uzupełnienia. Ze względu na brak kolejnych zgłoszeń z redakcji czasopism zdecydowano się rozesłać stosowne informacje do wszystkich, którzy otrzymali dane w 2015 r. Odzew był niemal natychmiastowy i rozpoczęto sukcesywne przekazywanie danych.

Następnie podjęto decyzje o skierowaniu maili również do przedstawicieli tych czasopism, które nie wprowadziły danych w 2015 r., rezygnując — świadomie bądź nie - z gratyfikacji w postaci kilku punktów w ramach oceny cza-

${ }^{45}$ Ustawa z dnia 30 kwietnia 2010 r. o zasadach finansowania nauki, art. 4c, ust. 4, pkt 2. 
sopism. Wśród reakcji zwrotnych znalazły się np. takie: „Proszę o krótkie wyjaśnienie, o co chodzi”, „Nie byłem świadomy, że w ubiegłym roku coś takiego było potrzebne i możliwe”. Po objaśnieniach ze strony BazTech często proszono o przesłanie danych również z lat poprzednich.

Do twórców BazTech wpłynęło też kilka próśb o przesłanie danych z redakcji czasopism z listy ministerialnej A. W związku z tym zwrócono się do MNiSW oraz operatora POL-indexu (OPI-PIB) z prośbą o wykładnię prawną. Nie otrzymano odpowiedzi z MNiSW, a z OPI-PIB jedynie przypuszczenie, że chodzi o czasopisma $\mathrm{z}$ listy $\mathrm{B}$. W związku z tym czasopisma $\mathrm{z}$ listy A, których redakcje zwróciły się do BazTech o dane, otrzymały je, choć miały później problem z eksportem do POL-indexu, gdyż nie składały ankiet ewaluacyjnych i w PBN nie istniały rekordy tytułów ich czasopism.

Ustawowy termin wprowadzenia do POL-indexu danych z 2015 r. mijał 30 kwietnia 2016 r., a na początku kwietnia nastąpiła zmiana operatora systemu (z ICI na OPI-PIB). Skutkowało to m.in. problemami technicznymi — do systemu nie było dostępu przez prawie dwa tygodnie. Fakt ten spowodował lawinę maili do twórców BazTech. Ostatecznie wszyscy, którzy zamierzali wprowadzić dane, mogli to uczynić tuż przed 30 kwietnia. Praktycznie nie było zatem czasu na ich weryfikację i ewentualne poprawki. Należy pamiętać, że — zgodnie z założeniami POL-indexu — za poprawność danych odpowiedzialność ponoszą redakcje czasopism, a nie twórcy baz bibliograficznych. Na pytania o możliwość przedłużenia ustawowego terminu wprowadzenia danych otrzymano odpowiedź negatywną. Ostatecznie dostępu do POL-indexu nie zamknięto po 30 kwietnia 2016 r. i dane można nadal eksportować.

W wyniku wsparcia czasopism naukowych z zakresu nauk technicznych w 2016 r. Konsorcjum BazTech przekazało pliki .xml z danymi bibliograficznymi, gotowymi do wyeksportowania do POL-indexu, do 172 czasopism, z czego do 20 czasopism po ustawowym terminie 30 kwietnia. Większość redakcji zwracała się o dane z 2015 r. Dziewięciu redakcjom, które nie eksportowały plików w 2015 r., przesłano dane z lat 2009-2015. Redakcje 56 czasopism, które otrzymały pliki w 2015 r., nie zwróciły się o dane w 2016 r. Można jedynie przypuszczać, że przyczyną tego był brak oceny czasopism i zachęty „punktowej” w 2016 r. Łącznie przekazano opisy ok. 13 tys. artykułów.

Należy zwrócić uwagę na różnice $\mathrm{w}$ liczbach czasopism zainteresowanych wprowadzeniem danych do POL-indexu w roku 2015 i 2016 (tabela 1). W 2015 r. zasilanie systemu było związane z możliwością zdobycia dodatkowych punktów przy ocenie czasopisma i każda redakcja wypełniająca ankietę ewaluacyjną napotykała kryterium oceny „POL-index” — stąd większej liczbie czasopism (216) przesłano pliki. W $2016 \mathrm{r}$. nie przeprowadzono oceny czasopism i - mimo wspominanego tu wielokrotnie ustawowego obowiązku wprowadzania danych do POL-indexu — większość redakcji nie miała tej wiedzy i nie zwracała się o dane do baz bibliograficznych. Sądząc po danych przedstawionych w tabeli 1, duża liczba 
czasopism, którym przekazano dane z BazTech w 2016 r. (172) — w porównaniu z innymi bazami - wynikała $\mathrm{z}$ faktu, że większość redakcji została przez twórców BazTech poinformowana o możliwości generowania danych.

\section{Wnioski}

Wnioski wynikające z dotychczasowej współpracy różnych podmiotów w zakresie tworzenia systemu POL-index sformułujemy w formie katalogu plusów i minusów, czyli słabych i mocnych stron tej współpracy i samego POL-inde$\mathrm{xu}$, oraz wynikających z niej szans i zagrożeń dla dalszego rozwoju. Partnerami współpracy są zarówno redakcje i/lub wydawcy czasopism naukowych, jak i bazy bibliograficzne, twórcy i operatorzy POL-indexu oraz właściciel systemu - MNiSW. Plusy i minusy oraz szanse i zagrożenia współpracy (czy jej bra$\mathrm{ku}$ ) dotyczą w różnym stopniu wszystkich podmiotów współpracy i każdy może z tworzenia POL-indexu czerpać zyski albo straty. Wnioski zostaną sformułowane na podstawie doświadczeń twórców bazy danych BazTech w powiązaniu z aktami prawnymi i danymi liczbowymi dotyczącymi samego POL-indexu czy też baz bibliograficznych.

\section{Plusy współpracy przy tworzeniu POL-indexu}

Właściciel i operator POL-indexu powinni dostrzegać zalety aktywnego udziału baz bibliograficznych w zasilaniu systemu danymi za pośrednictwem redakcji czasopism. Dzięki temu do POL-indexu terminowo trafiają wiarygodne i pełne dane bibliograficzne z większości baz z bibliografiami załącznikowymi.

Udział w tworzeniu POL-indexu jest nowym działaniem baz bibliograficznych, w którym twórcy — poza wieloma problemami — dostrzegają sporo plusów. Doświadczenia BazTech pokazują, że przekazywanie danych redakcjom w ściśle określonych terminach wymusiło szczególną dbałość o aktualizację i kompletność danych w bazie. $Z$ drugiej strony zaangażowanie twórców bazy spotkało się z dużym wsparciem ze strony redakcji/wydawców czasopism, co owocowało umożliwianiem dostępu on-line do danych w witrynach czasopism w celu szybszego indeksowania oraz przesyłaniem bibliotekom darmowych egzemplarzy drukowanych. Trzeba też wspomnieć o najprzyjemniejszych aspektach współpracy przy tworzeniu POL-indexu: wzroście prestiżu baz bibliograficznych, a także osobistej satysfakcji bibliotekarzy indeksujących czasopisma. Twórcy BazTech otrzymali wiele pochlebnych opinii, np.:

Bardzo dziękuję za przesłane dane i nieocenioną pomoc :) Gratuluję świetnie wykonanej pracy!

Pięknie dziękuję za ogromną pomoc i kłaniam się nisko wspaniałym pracownikom BazTech. 
Jest to dla mnie ogromna pomoc i zarazem zaoszczędzenie mnóstwa czasu!

Dzięki Waszej bazie import do POL-index to czysta przyjemność.

Bardzo cenimy sobie Państwa działalność indeksacyjną. Stanowi ona dla Redakcji [...] wielką pomoc.

\section{Minusy współpracy przy tworzeniu POL-indexu}

Do najbardziej dotkliwych w skutkach słabych stron procesu tworzenia POL-indexu — w odczuciu twórców baz danych, jak również redakcji czasopism — należą:

1. niekonsekwencje w przepisach prawnych:

- nie wszystkie ustawy, rozporządzenia czy komunikaty MNiSW precyzują wyraźnie, kto jest odpowiedzialny za przekazywanie danych do POL-indexu, wskazując tylko źródła danych (redakcje czasopism lub bazy bibliograficzne), oraz czy dane powinny pochodzić z czasopism tylko z listy ministerialnej B czy również A i C?

— zgodnie z niektórymi przepisami wprowadzanie danych do POL-indexu ma charakter dobrowolny i jest premiowane dodatkowymi punktami przy ocenie czasopism ${ }^{46}$, natomiast inne przepisy zobowiązują wydawców czasopism do wprowadzania danych ${ }^{47}$;

— różnie definiuje się zestaw danych pełnych rekordów bibliograficznych wymaganych w POL-indexie oraz nie zawsze wyszczególnia się dane obowiązkowe i fakultatywne;

2. niezadowalająca wśród wydawców czasopism znajomość przepisów prawnych oraz wiedza o możliwości skorzystania ze wsparcia baz bibliograficznych czy w ogóle o istnieniu takich baz (należy pamiętać, że czasopisma naukowe wydawane są zarówno przez duże wydawnictwa, jak i przez niewielkie zespoły pracowników naukowych z instytutów, katedr szkół wyższych czy instytutów badawczo-rozwojowych); świadczą o tym przykładowe wypowiedzi:

W związku z koniecznością stworzenia bazy danych w POL index w celu uzyskania 2 pkt $\mathrm{w}$ ocenie czasopisma naukowego proszę o przekazanie informacji co redakcja czasopisma musi wykonać aby wykorzystać do tego celu dane Baz Tech z lat 2009-2015;

Czy wiadomo może kiedy mija termin dostarczania danych za 2015 rok? Czy tu też będziemy mogli liczyć na Państwa pomoc?

Dziękuję serdecznie za informację oraz możliwość wsparcia czasopism we wprowadzaniu danych do POL-index. Nie spodziewałem się, że istnieje taka możliwość;

${ }^{46}$ Komunikat Ministra Nauki i Szkolnictwa Wyższego z dnia 29 maja 2013 r.; Komunikat w sprawie przedłużenia terminu wprowadzania danych do polskiej bazy cytowań POL-index.

${ }^{47}$ Ustawa z dnia 15 stycznia 2015 r. o zmianie ustawy o zasadach finansowania nauki oraz niektórych innych ustaw. 
3. różnice w formatach danych obowiązujących w POL-indexie i w bazach bibliograficznych oraz różnice pomiędzy formatami w samych bazach powodujące braki w danych wymaganych przez MNiSW, które musiały być uzupełniane przez redakcje czasopism (np. pełne imiona autorów); niektóre dane - nieobowiązkowe - nie były eksportowane $\mathrm{z}$ baz bibliograficznych, mimo że tam występują (np. numery DOI artykułów, słowa kluczowe czy afiliacje autorów) i z pewnością wpłynęłyby na wyższą jakość POL-indexu;

4. częste zmiany operatorów POL-indexu, skutkujące rewizjami zasad i trybu wprowadzania danych do systemu;

5. brak (testowego) dostępu do POL-indexu dla twórców baz bibliograficznych, utrudniający pomoc redakcjom czasopism w eksportowaniu plików z danymi.

\section{Szanse wynikające ze współpracy}

Pomimo wielu minusów dostrzeganych w procesie tworzenia POL-inde$\mathrm{xu}$ widzimy również pewne szanse korzystnych zmian zarówno dla samego POL-indexu, jak i baz bibliograficznych. Omawiane w niniejszym tekście bazy bibliograficzne tworzące Bibliotekę Nauki oraz inne krajowe bazy wymieniane na ministerialnej liście baz referencyjnych indeksują łącznie zdecydowaną większość czasopism punktowanych przez MNiSW i znajdujących się na listach A, B i C. Według danych z ARIANTY z 13 września 2016 r. rozkład tych czasopism jest następujący: AGRO - 263, BazEkon - 219, BazHum - 448, BazTech — 413, CEJSH - 715, DML PL — brak danych, Polska Bibliografia Lekarska — 350, PSJD - 6. Suma daje 2414 tytuły, których część występuje w kilku bazach $^{48}$. Nie zmienia to jednak faktu, że zasoby krajowych baz bibliograficznych stanowią ogromny potencjał, którego znaczenie podkreśliła wcześniej Aneta Drabek, opowiadając się za „wykorzystaniem tych istniejących źródeł, a także za tym, żeby te banki danych były wspierane, rozwijane i doceniane w polityce naukowej państwa"49.

Pozyskiwanie danych do POL-indexu w całości z baz bibliograficznych było również optymalnym wariantem przepływu danych, zakładanym przez twórców systemu, wymagającym jednakże indeksacji w tych bazach wszystkich czasopism aplikujących o ocenę w ramach części B wykazu czasopism punktowanych ${ }^{50}$. Takie rozwiązanie jest nadal możliwe do zrealizowania, gdyż w POL-indexie istnieje me-

${ }^{48}$ L. Derfert-Wolf, op. cit., s. 198-199.

49 A. Drabek, Do użytku bibliometrycznego... Niebibliograficzne wykorzystanie baz bibliograficznych, [w:] Bibliograficzne bazy danych i ich rola $w$ rozwoju nauki. II konferencja naukowa Konsorcjum BazTech, Poznań 17-19 kwietnia 2013, „EBIB — Materiały Konferencyjne” 24, http://open.ebib.pl/ojs/index.php/Mat_konf/article/view/26/15 [dostęp: 13.02.2017].

${ }^{50} \mathrm{~W}$. Fenrich et al., op. cit. 
chanizm jednorazowego importu całej bazy bibliograficznej. Redakcje uniknęłyby wtedy występowania do twórców baz o przygotowanie plików z danymi dla poszczególnych czasopism, a koordynatorzy baz nie mieliby dodatkowej pracy z generowaniem setek plików. W takim podejściu twórcy baz mogą upatrywać również szansy dla rozwoju swoich serwisów, przejawiającej się głównie w ciągłym finansowaniu gwarantującym aktualność i kompletność danych z indeksowanych czasopism.

\section{Zagrożenia dla rozwoju POL-indexu}

Na podstawie danych przedstawionych w tabeli 1 łatwo można wywnioskować, że w 2016 r. nastąpił znaczny spadek liczby czasopism, którym bazy bibliograficzne przekazały dane. Nie dysponujemy jeszcze danymi z POL-indexu dotyczącymi liczby wprowadzonych opisów artykułów. Opierając się na zebranych danych oraz opinii twórców baz bibliograficznych, można przypuszczać, że w 2016 r. dane z 2015 r. wprowadziło/wyeksportowało dużo mniej redakcji czasopism. Proste wyszukiwanie w POL-indexie wskazuje na 74737 rekordów artykułów z 2014 r., a tylko 29474 rekordy z 2015 r. Przyczyn należy upatrywać w podkreślanym wcześniej niedostatecznym informowaniu redakcji czasopism o obowiązku sprawozdawczym. Zatem największym zagrożeniem dla dalszego rozwoju POL-indexu jest obniżanie wskaźnika kompletności bazy i wynikające w tego niemiarodajne rezultaty obliczania PWW. Należy tu dodać, że obowiązek sprawozdawczości w zakresie danych o działalności badawczo-rozwojowej $\mathrm{w}$ tym danych o cytowaniach $\mathrm{w}$ artykułach $\mathrm{z}$ czasopism - dotyczy tylko jednostek naukowych ${ }^{51}$. Czasopisma wydawane przez inne podmioty, a szczególnie firmy komercyjne, mogą więc, ale nie muszą, wprowadzać dane do POL-indexu. Jedyną zachętą dla nich jest gratyfikacja w postaci kilku punktów przy ocenie czasopism przez MNiSW.

Kolejnym zagrożeniem — tym razem dla redakcji i wydawców czasopism, które korzystają ze wsparcia baz bibliograficznych - jest brak dofinansowania tych baz, który w dłuższej perspektywie spowoduje znaczny spadek aktualności danych i brak możliwości przekazywania plików z danymi do POL-indexu. W takiej sytuacji przedstawiciele czasopism będą zmuszeni wprowadzać dane we własnym zakresie.

\section{Podsumowanie}

Z przedstawionych plusów i minusów współpracy oraz szans i zagrożeń rozwoju POL-indexu i baz bibliograficznych wynika, że działań naprawczych

${ }^{51}$ Ustawa z dnia 30 kwietnia 2010 r. o zasadach finansowania nauki. 
wymaga nie tylko POL-index, lecz także same bazy. Najważniejsze wydaje się zapewnienie bardziej skutecznego przepływu informacji o POL-indexie i zagwarantowanie wszystkim redakcjom czasopism możliwości skorzystania ze wsparcia baz bibliograficznych w zasilaniu systemu danymi. Doskonałym udogodnieniem byłaby taka informacja $\mathrm{w}$ ankiecie aplikacyjnej oceny czasopism. Z drugiej strony ważne jest ujednolicenie formatów danych oraz zapewnienie aktualności i kompletności baz bibliograficznych, szczególnie w kontekście indeksowanych czasopism punktowanych przez MNiSW.

Twórcy baz danych poprzez swe działania w ramach tworzenia POL-indexu dali przykłady dobrych praktyk, wspierając redakcje czasopism, oszczędzając im wiele pracy. Dzięki tym działaniom nawiązała się również dobra współpraca z przedstawicielami czasopism, przynosząca często wymierne korzyści bazom danych. Twórcy baz od kilku lat wspólnie kształtują i realizują politykę promocji swoich systemów i otwartego dostępu do nauki. Pozostaje jedynie życzyć sobie lepszego współdziałania baz bibliograficznych z właścicielem oraz operatorem POL-indexu.

\section{Bibliografia}

BazTech — Baza danych o zawartości polskich czasopism technicznych, http://baztech.icm.edu.pl/ index.php/pl/dane-z-czasopism-baztech-do-pol-index [dostęp: 13.02.2017].

Brzeziński P., Szewczuk K., Kiliszek W., Polska Bibliografia Naukowa. Modut Sprawozdawczy i system POL-index oczami dotychczasowego operatora systemu - nowości, wyzwania, podsumowanie, ,Biuletyn EBIB” 2016, nr 3 (165), http://open.ebib.pl/ojs/index.php/ebib/article/view/432 [dostęp: 13.02.2017].

Derfert-Wolf L., Indeksowanie czasopism naukowych w krajowych bazach danych w kontekście organizacyjno-ekonomicznym, [w:] Biblioteka akademicka: infrastruktura-uczelnia-otoczenie, red. M. Odlanicka-Poczobutt, K. Zioło, Gliwice 2014, s. 191-207.

Drabek A., Do użytku bibliometrycznego... Niebibliograficzne wykorzystanie baz bibliograficznych, [w:] Bibliograficzne bazy danych i ich rola w rozwoju nauki. II konferencja naukowa Konsorcjum BazTech, Poznań 17-19 kwietnia 2013, „EBIB - Materiały Konferencyjne” 24, http:// open.ebib.pl/ojs/index.php/Mat_konf/article/view/26/15 [dostęp: 13.02.2017].

Fenrich W. et al., POL-index - Polska Baza Cytowań, [w:] Bibliograficzne bazy danych i ich rola w rozwoju nauki. II konferencja naukowa Konsorcjum BazTech, Poznań 17-19 kwietnia 2013, „EBIB - Materiały Konferencyjne” 24, http://open.ebib.pl/ojs/index.php/Mat_konf/article/ view/40/ [dostęp: 13.02.2017].

Flis D., Zmora humanistów - bibliografia, „Gazeta Wyborcza” 17.08.2015, http://wyborcza. pl/1,75398,18579671,zmora-humanistow-bibliografia.html [dostęp: 13.02.2017].

Komunikat Ministra Nauki i Szkolnictwa Wyższego z dnia 2 czerwca 2015 r. w sprawie kryteriów i trybu oceny czasopism naukowych.

Komunikat Ministra Nauki i Szkolnictwa Wyższego z dnia 29 maja 2013 r. w sprawie kryteriów i trybu oceny czasopism naukowych.

Komunikat w sprawie przedłużenia terminu wprowadzania danych do polskiej bazy cytowań POL-index - pismo Sekretarza Stanu prof. Marka Ratajczaka z dnia 20 lipca 2015 r., http://www.nauka.gov.pl/komunikaty/komunikat-w-sprawie-przedluzenia-terminu-wprowadzania-danychdo-polskiej-bazy-cytowan-pol-index.html [dostęp: 13.02.2017]. 
Kulczycki E., Polski Współczynnik Wpływu, [w:] Warsztat badacza, 25.08.2013, http://ekulczycki.pl/ warsztat_badacza/polski-wspolczynnik-wplywu/ [dostęp: 13.02.2017].

Kulczycki E., Zasady oceny czasopism w 2015: omówienie i komentarz, [w:] Warsztat badacza, 3.06.2015, http://ekulczycki.pl/warsztat_badacza/zasady-oceny-czasopism-w-2015-omowienie-i-komentarz/ [dostęp: 13.02.2017].

Kulczycki E., Rozkosz E.A., Drabek A., Ocena ekspercka jako trzeci wymiar ewaluacji krajowych czasopism naukowych, „Nauka” 2016, nr 1, s. 107-142.

POL-index, https://pbn.nauka.gov.pl/polindex-webapp/ [dostęp: 13.02.2017].

Przyłuska J., System Informacji o Nauce — zakres danych i informacji objętych systemem, terminy aktualizacji i sposób udostępniania danych, „Biuletyn EBIB” 2016, nr 3 (165), http://open.ebib. pl/ojs/index.php/ebib/article/view/425 [dostęp: 13.02.2017].

Rozporządzenie Ministra Nauki i Szkolnictwa Wyższego z dnia 26 lutego 2016 r. zmieniające rozporządzenie w sprawie Systemu Informacji o Nauce, Dz.U. 2016, poz. 309.

Rozporządzenie Ministra Nauki i Szkolnictwa Wyższego z dnia 27 października 2015 r. w sprawie kryteriów i trybu przyznawania kategorii naukowej jednostkom naukowym, Dz.U. 2015, poz. 2015.

Rozporządzenie Ministra Nauki i Szkolnictwa Wyższego z dnia 29 czerwca 2015 r. w sprawie Systemu Informacji o Nauce, Dz.U. 2015, poz. 944.

Ustawa z dnia 15 stycznia 2015 r. o zmianie ustawy o zasadach finansowania nauki oraz niektórych innych ustaw, Dz.U. 2015, poz. 249.

Ustawa z dnia 30 kwietnia 2010 r. o zasadach finansowania nauki, Dz.U. 2010, nr 96, poz. 615 z późn. zm.

\title{
Bibliographic databases and POL-index strengths, weaknesses, opportunities and threats - based on BazTech experience
}

\author{
Summary
}

The theme of the article is focused on creating a Polish citation database POL-index in the context of cooperation between the various data providers: the editors / publishers of journals and bibliographic databases. It presents the concept of the POL-index and the Polish Impact Coefficient as well as the related legal acts, POL-index management and its contents. It also explains the experiences of bibliographic databases creators associated with transmission of metadata of the articles from scientific journals to POL-the index. The article indicates the best practices of these activities of BazTech database, especially the various aspects of cooperation with the journal editors. The aim of the article is to analyze the strengths and weaknesses of cooperation between different partners in creating of POL-index, opportunities and threats for further development of the system itself, as well as bibliographic databases. The method of literature's analysis, primary source and statistical data were used. Conclusions - The most important strengths of the cooperation in the POL-index are benefits for databases, including greater timeliness and completeness of data as well as an increase of importance of these services. The weaknesses were: inconsistencies in the law, lack of satisfactory information among publishers, diversity of data formats and frequent changes of POL-index operators. The key opportunity is the potential of the bibliographic databases, which may constitute the core of POL-index, and the threat - lower rate of completeness of the citations in the POL-index.

KEYWORDS: bibliographic databases, BazTech, POL-index, cytation analysis, scientific journals. 